Thabiea : Journal of Natural Science Teaching
Program Studi Tadris Ilmu Pengetahuan Alam
Institut Agama Islam Negeri Kudus
http://journal.stainkudus.ac.id/index.php/Thabiea
$p$-issn: 25808474

\title{
Tingkat Pemahaman Konsep Siswa pada Materi Momen Gaya
}

\author{
Dody Rahayu Prasetyo ${ }^{\mathrm{a}, 1}$ \\ a IAIN Kudus, Jalan Conge Ngembalrejo No.51, Ngembal Rejo, Ngembalrejo, Bae, Kabupaten Kudus, Jawa Tengah 59322 \\ ${ }^{1}$ dodyslash89@gmail.com
}

\begin{tabular}{ll}
\hline Kata kunci: & ABSTRAK \\
\hline Tingkat Pemahaman Konsep & Penelitian ini bertujuan untuk mengungkap tingkat pemahaman konsep \\
Momen gaya & siswa dan faktor penyebabnya tentang konsep momen gaya. Sejumlah 71 \\
Intuisi & siswa terdiri dari 36 siswa kelas XI IPA dan 25 siswa kelas XII IPA \\
Kurang Pemahaman & diberikan tes tertulis terbuka terkait materi momen gaya. Hasil tes tertulis \\
Fragmentasi & dikategorikan menjadi respon ilmiah, respon tidak ilmiah, dan tidak \\
Apresiasi Konseptual & merespon. Diambil sebanyak 30 siswa yang memiliki respon yang \\
& dominan untuk dilakukan wawancara dan pengambilan sampel didasarkan \\
& pada opportunity sampling. Berdasarkan hasil analisis kualitatif tes tertulis \\
& dan wawancara disimpulkan bahwa (1) respon tak ilmiah lebih \\
& mendominasi pada kedua kelas dan (2) penyebabnya dipengaruhi oleh \\
& beberapa faktor yaitu: intuisi, kurang pemahaman, fragmentasi, dan \\
apresiasi konseptual.
\end{tabular}

\begin{tabular}{ll}
\hline Keyword: & ABSTRACT \\
\hline The level of understanding of & This study aims to reveal the level of understanding of students' concepts \\
students' concepts & and their causal factors about the concept of torque. A total of 71 students \\
Torque & consisting of 36 students of class XI IPA and 25 students of class XII IPA \\
Intuition & were given an open ended test about torque. The open ended test results \\
Fragmentation & are categorized as scientific responses, unscientific responses, and no \\
Conceptual Appreciation & respons. Taken as many as 30 students who have the dominant response \\
& for interviews and sampling is based on opportunity sampling. The results \\
of the qualitative analysis of written tests and interviews concluded that \\
(1) unscientific responses dominate in both classes and (2) the causes are \\
influenced by several factors, namely: intuition, fragmentation, and \\
conceptual appreciation
\end{tabular}

Copyright () 2018 Institut Agama Islam Negeri Kudus. All Right Reserved

\section{Pendahuluan}

Penyebab pelajaran fisika sulit bagi siswa adalah pemahaman konsep yang digunakan lebih cenderung pada konsep permukaan (Linuwih, 2010). Hal yang sama ditemukan oleh Samudra et al. (2014), penyebab kesulitan belajar fisika siswa Singaraja adalah materi fisika yang padat, menghafal, menghitung, dan pembelajaran fisika di kelas tidak kontekstual (Samudra et al., 2014). Pemecahan masalah fisika yang bersifat kuantitatif membuat penguasaan konsep siswa menjadi dangkal/hanya sebatas pada konsep permukaan. Hal ini didukung dari hasil penelitian Sarkity et al (2016) menunjukan bahwa siswa lebih cenderung mampu menyelesaikan soal kuantitatif dibandingkan soal kualitatif. Namun, pada soal kuantitatif yang melibatkan beberapa konsep, siswa akan mengalami kebingungan dalam pemecahannya. Menurut pendapat Linuwih et al (2010), siswa menganggap fisika adalah kumpulan beberapa konsep yang tidak saling berhubungan. Ditambahkan oleh Suparno (2001) dari teori konstruktivisme Piaget, pengetahuan/konsep siswa tentang suatu benda atau hal merupakan bentukan (konstruksi) dari orang tersebut. Jadi, siswa cenderung mengalami kesulitan dalam pemecahan masalah fisika, yang disebabkan oleh beberapa faktor. 
Tanpa adanya usaha oleh guru untuk mencari akar permasalahan/faktor penyebab kesulitan belajar fisika, pelajaran fisika tetap akan menjadi momok bagi siswa. Karena setiap siswa memiliki tingkat kecerdasan yang berbeda, tentunya tingkat pemahaman konsep fisika juga berbeda. Sarioglan (2016) mengelompokkan tingkat pemahaman konsep siswa menjadi tiga yaitu: respon ilmiah, respon tidak ilmiah, dan tidak merespon. Respon ilmiah yang dimaksud adalah jawaban siswa yang sesuai dengan konsep pakar, respon tidak ilmiah yaitu jawaban siswa yang tidak sesuai dengan konsep pakar, sedangkan tidak merespon yaitu siswa tidak memberikan jawaban. Berdasarkan penjelasan diatas, tentunya pada tingkat pemahaman konsep siswa yang tidak ilmiah menjadi menarik untuk dibahas.

Rahmawati et al (2017), Amnirullah (2015), dan Sarkity et al (2016) telah melakukan peneltian tentang kesulitan siswa dalam memahami konsep momen gaya. Momen gaya merupakan penyebab benda mengalami rotasi (Giancoli, 2001). Bentuk matematis dari momen gaya dapat dituliskan $\vec{\tau}=\vec{r} \times \vec{F}$. Namun, mereka belum membahas faktor-faktor yang menjadi penyebabnya. Pada materi fluida dan dinamika partikel, Setyo et al (2014), Linuwih (2013), dan Linuwih et al (2010) menemukan faktor penyebab kesulitan siswa yaitu: pemahaman kurang mendalam, fragmentasi, pengetahuan sebagai struktur teori. Artikel ini ingin mengungkapkan faktor-faktor penyebab kesulitan siswa dalam memahami materi momen gaya.

\section{Metode}

Metode penelitian dalam penelitian ini menggunakan metode kualitiatif deskriptif. Dalam pengumpulan data, penelitian ini menggunakan dua tahapan yaitu tes tertulis (open ended) dan wawancara. Pada tes tertulis melibatkan 61 siswa MA Muwahidun yang terdiri dari 36 siswa kelas XI dan 25 siswa kelas
XII yang telah mendapatkan materi dinamika rotasi. Soal tes tertulis berjumlah 4 dan terfokus pada konsep momen gaya. Soal tes tersebut disajikan seperti berikut.

\section{Soal 1}

Sebuah batang bermassa diberi poros pada salah satu ujungnya sehingga dapat berputar dengan bebas. Jika batang dipegang disalah satu ujung lainnya sehingga posisinya horisontal seperti pada gambar di bawah ini, apakah yang terjadi pada batang ketika ujung batang dilepas?beri penjelasan!

\section{Soal 2}

Tiga buah roda pejal bermassa dan berjari-jari sama berada bidang datar yang kasar ditarik dengan gaya yang besarnya sama tetapi arahya berbeda seperti gambar. Kemanakah arah gerak masing-masing roda?beri penjelasan!

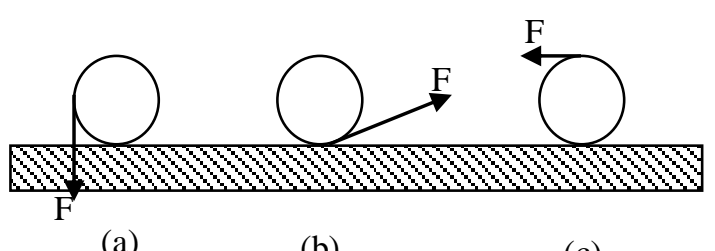

\section{$\underline{\text { Soal } 3}$}

Suatu roda berbentuk silinder pejal berjari-jari $R$ dapat berputar bebas terhadap pusat roda, anggap tidak ada gesekan antara as roda dengan besi. Awalnya roda diam tidak bergerak, kemudian hinggap lalat pada posisi horisontal dan menempel pada permukaan roda tanpa slip, ditunjukkan seperti pada gambar. Apakah roda akan berputar? jika ya, beri penjelasan faktor yang menjadi penyebabnya?

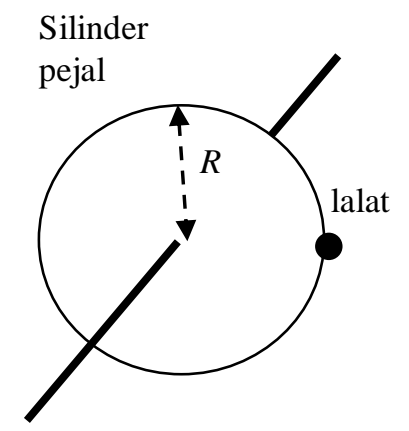




\section{Soal 4}

Terdapat dua silinder pejal memiliki jari-jari dan massa sama berada bidang yang berbeda, bergerak horisontal dengan kecepatan yang sama sebesar $v$ seperti pada gambar di bawah.

(a)

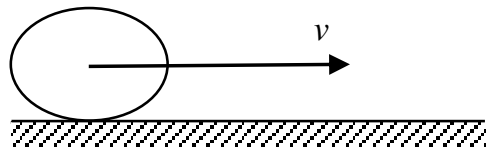

licin

(b)

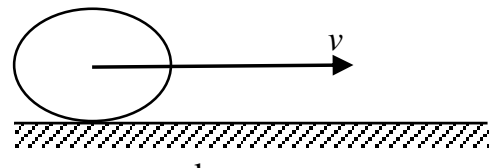

kasar

Wawancara dibutuhkan untuk mengungkapkan secara mendalam jawaban dari siswa. Hasil jawaban tes tertulis dapat dimungkinkan, siswa menjawabnya dengan asal-asalan atau meniru temannya. Siswa yang diambil untuk diwawancarai sebanyak 30 siswa (kelas XI dan XII). Sampel yang diambil ini berdasarkan sampling opportunistic sampling (Sugiyono, 2013).

\section{Hasil dan pembahasan}

Hasil tes tertulis yang diperoleh kemudian dikelompokkan berdasarkan tingkat pemahaman konsep. Tingkat pemahaman konsep untuk nomor 1 ditunjukkan pada Gambar 1.

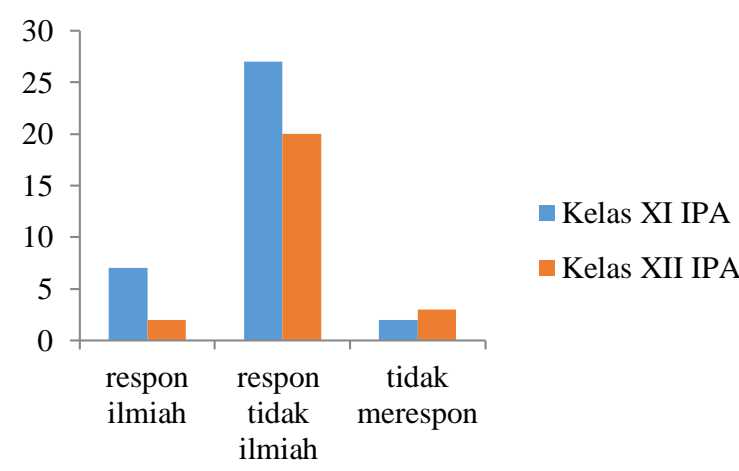

Gambar 1. Tingkat Pemahaman Konsep Soal 1
Dari Gambar 1 menunjukkan bahwa respon tidak ilmiah yang paling dominan di kelas XI dan XII IPA. Respon tidak ilmiah yang ditunjukkan dengan siswa meyakini bahwa jika tidak ada gaya eksternal yang bekerja pada benda, maka benda akan diam. Dalam hal ini berarti siswa menggunakan apresiasi konseptual dan kurang pemahaman. Linuwih (2013) dan Linuwih et al (2010) menyatakan bahwa siswa menyakini suatu konsep selalu cocok digunakan untuk semua kasus. Ada juga siswa yang menyakini bahwa benda yang dapat berotasi tidak harus bekerja gaya. Menurut mereka, pada soal tidak tertulis adanya gaya, sehingga pada benda juga tidak ada gaya. Hal ini menunjukkan bahwa kurangnya pemahaman siswa terkait konsep gaya berat. Setyo et al (2014) menyatakan bahwa siswa mengalami kesulitan dalam pemecahan masalah disebabkan salah satunya mereka kurang pemahaman.

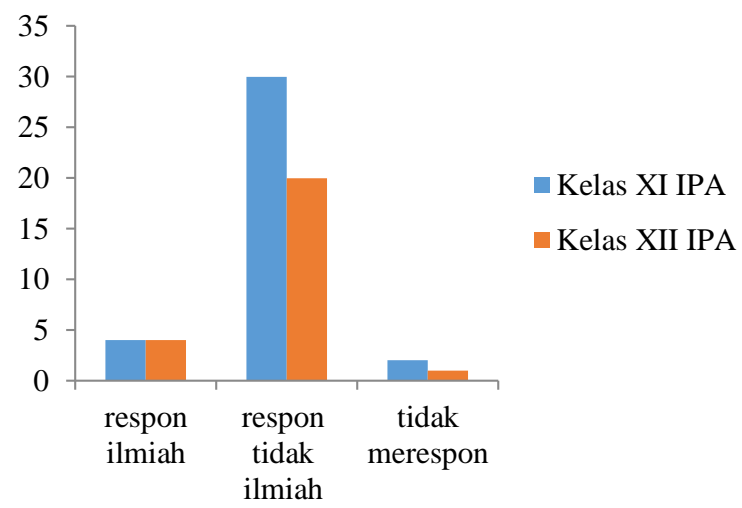

Gambar 2. Tingkat Pemahaman Konsep Soal 2

Dari Gambar 2 menunjukkan respon tidak ilmiah yang paling dominan di kelas XI dan XII IPA. Respon siswa pada Gambar (a) sangat beragam dalam menjawab arah gerak roda diantaranya: bergeser ke kanan, kiri, dan bahkan ada yang menjawab roda tetap diam. Siswa berpikir bahwa jika gaya bekerja disebelah kiri benda, maka benda akan bergeser ke kanan (dengan memperagakan). Dalam hal ini siswa menggunakan intuisi dalam pemecahan suatu permasalahan. Ada juga yang beripikir menggunakan intuisi yaitu jika benda 
ditekan ke arah bawah maka benda akan tetap diam. Respon siswa dalam menghadapi soal Gambar (b) diantaranya: ada yang menjawab benda bergerak ke kiri dan ada juga yang menjawab bergerak ke kanan. Dengan menggunakan intuisi, siswa berpikir jika benda dikenai gaya ke arah kanan, maka benda juga akan bergerak kanan. Sementara yang menyatakan roda bergerak ke kiri, menyakini bahwa gaya gesek memiliki peran dalam hal ini. Namun, mereka tidak dapat menjelaskan arah gaya gesek. Kasus ini dapa terjadi karena pemahaman siswa masih terfragmentasi. Semua respon siswa pada soal Gambar (c) telah sesuai dengan konsep ilmiah. Dari penjelasan diatas, siswa lebih menggunakan intuisi/pengalaman sehari-hari. Kesulitan siswa dalam menjelaskan suatu konsep disebabkan oleh masih terfragmentasi/terpecah-pecah. Hal ini sesuai dengan penjelasan Linuwih et al (2010), Linuwih (2013), dan Setyo, N et al, (2014).

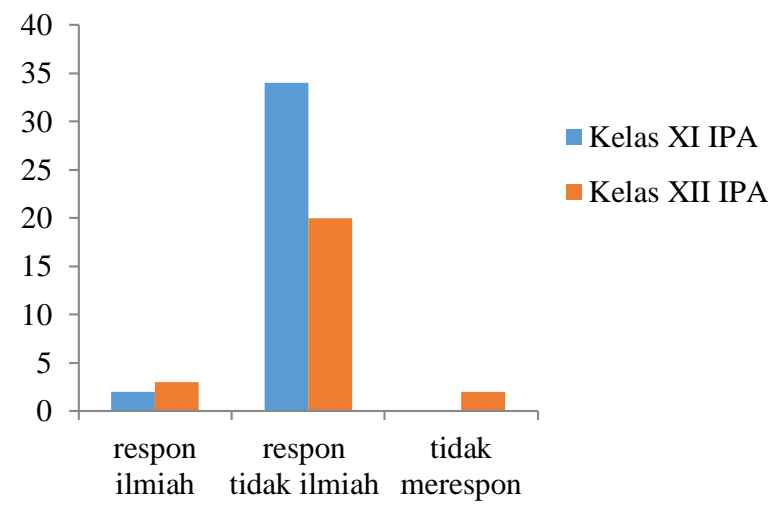

Gambar 3. Tingkat Pemahaman Soal Nomor 3

Dari Gambar 3 terlihat bahwa tingkat pemahaman konsep yang paling dominan adalah respon tidak ilmiah di kelas XI dan XII IPA. Respon tidak ilmiah yang dimiliki siswa sebagai berikut: (1) roda tidak akan berputar saat lalat hinggap dan (2) roda dapat berputar tergantung dari massa lalat. Siswa menggunakan intuisi, meyakini bahwa lalat yang hinggap di sebuah benda tidak membuat benda bergerak sesuai dengan pengalamannya sehari-hari mereka. Ada juga yang berpendapat bahwa benda dapat bergerak ketika dikenai gaya oleh benda yang ukurannya besar. Dari hal ini siswa menggunakan intuisi juga. Hal ini didukung oleh Linuwih (2013) dan Linuwih et al (2010).

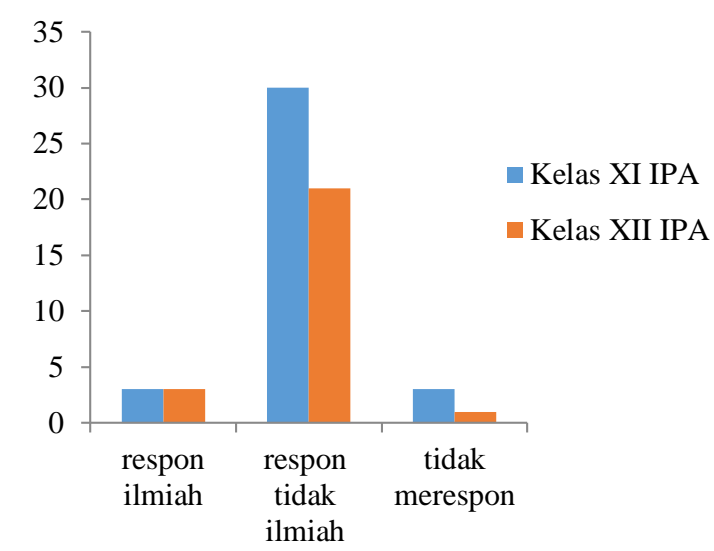

Gambar 4. Tingkat Pemahaman Konsep Soal 4

Dari Gambar 4 terlihat bahwa tingkat pemahaman konsep yang paling dominan adalah respon tidak ilmiah di kelas XI dan XII IPA. Siswa lebih meyakini bahwa roda (gambar b) bergerak menggelinding (translasi + rotasi) dibidang licin. Meskipun memahami keberadaan gaya gesek pada roda (gambar a) yang membuat roda menggelinding, siswa juga menggunakan konsep yang sama untuk diterapkan pada roda (gambar b) pada bidang yang licin. Hal ini faktor intuisi lebih mendominasi pemahaman siswa.

\section{Simpulan}

Berdasarkan analisis pada pembahasan, terdapat dua kesimpulan:

1. Tingkat pemahaman konsep pada kelas XI dan XII IPA relatif sama terutama "respon tidak ilmiah" yang mendominasi keduanya.

2. Faktor penyebab respon tidak ilmiah yaitu: intuisi, kurang pemahaman, fragmentasi, dan apresiasi konseptual

\section{Referensi}

Giancoli, D. C. 2001. Fisika Edisi Kelima Jilid 1. Terjemahan Yuhilza Hanum. Jakarta: Penerbit Erlangga. 
Linuwih, S. \& Setiawan, A. 2010. Latar Belakang Konsepsi Paralel Mahasiswa Pendidikan Fisika dalam Materi Dinamika. Jurnal Pendidikan Fisika Indonesia, 6(1).

Linuwih, S. 2013. Konsepsi Alternatif Mahasiswa Calon Guru Fisika tentang Gaya yang Bekerja pada Balok. Jurnal Pengajaran MIPA, 18(1).

Rahmawati, I., Sutopo, Zulaikah, S. 2017. Analysis of Students' Difficulties about Rotational Dynamics Based on Resources Theory. Jurnal Pendidikan IPA Indonesia, 6(1).

Samudra, G. B., Suastra, I. W., \& Suma, K. 2014. "Permasalahan-Permasalahan yang Dihadapi Siswa SMA di Kota Singaraja dalam Mempelajari Fisika”. $e$ Journal Progam Pascasarjana Universitas Pendidikan Ganesa, 4: 1-7.

Sarkity, D., Yuliati, L., \& Hidayat, A. 2016. Kesulitan Siswa SMA dalam Memecahkan
Masalah Kesetimbangan dan Dinamika Rotasi. Prosiding Semnas Pend. IPA Pascasajana UM, 1 (1).

Sarioglan, A. B. 2016. Conceptual Level of Understanding about Sound Concept: Sample of Fifth Grade Students. E-Journal of Educational Research, 7(1).

Setyo, F. \& Linuwih, S. 2014. Analisis Pemahaman Siswa SMA Terhadap Fluida pada Hukum Archimedes. Pros. Seminar Nasional Sains dan Pendidikan Sains IX, Fakultas Sains dan Matematika, UKSW, 5(1).

Sugiyono. 2013. Metode Penelitian Kuantitatif, Kualitatif, dan $R \& D$. Bandung: Alfabeta.

Suparno, P. 2001. Teori Perkembangan Kognitif Jean Piaget. Yogyakarta: Penerbit Kanisius. 